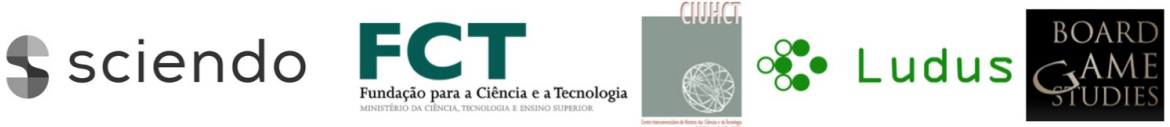

\section{REMEMBERING YUGOSLAVIA: BOARD GAME MONOPOLY AND GULTURAL MEMORY}

\author{
Zala Pavšic \\ Faculty of Media, Ljubljana, Slovenia
}

\begin{abstract}
The article is dedicated to exploring the relationship between board games and cultural memory, the board game in question being a version of Monopoly which was published in Yugoslavia in 1986. To address this question, I conducted several interviews with interlocutors who used to play the Yugoslavian version of Monopoly and grew up in the eighties or in the nineties. Apart from exploring Monopoly as a metaphor and showing the specifics of the Yugoslavian version, the article aims to outline the potential of a board game to reproduce traces of cultural memory and how these traces are interpreted differently according to the generational and socio-historical background of the interlocutors included in my research. Moreover, the purpose of my article is to show that board games should not be analyzed only in terms of their physical attributes, fields and the playing cards they include, but also with regard to their reception.
\end{abstract}

\section{Introduction}

The article at hand is based on the assumption that the abstract is the other side of the material or that material objects contain an abstract dimension as well (Miller 2017, 108). I will explore this relationship in the case of the board game Monopoly, more precisely its Yugoslav version, which was developed by the company Kocka in the mid-eighties. In doing so, I will deal not only with the distribution and evaluation of the playing fields and their possible symbolism, but above all with the reception of the game and the generation-specific memory associated with the game.

In his monograph on the social revolution of the eighties, Božo Repe notes that the Yugoslav peoples began to alienate from each other during the said period despite decades of joint cohabitation and that stereotypical impressions were gaining an ever-increasing role due to the lack of mutual understanding. "For the younger generation in the eighties, Yugoslav consciousness only functioned when it came to sports (especially soccer and basketball) and Yugoslav rock music" (2017, 19). Traditional school 
excursions and prom trips, increasingly reoriented towards Western countries, certainly did not help to consolidate common Yugoslav cultural space. Considering that the Yugoslav version of Monopoly represented tourist resorts of the former Yugoslavia, the goal of my research is to determine how these playing fields were experienced by interlocutors who no longer belonged to Yugoslav cultural space and were growing up in the period after the disintegration of the country. Thus, even more than in remembering, I will be interested in forgetting as a category that goes hand in hand with remembrance.

The significance of forgetting for memory studies has already been noted by many eminent theoreticians in the described field, including the French anthropologist Marc Augé, who saw forgetting as a premise for "returning us to the present" (2004, 89). A growing emphasis on the importance of forgetting was also the reason that led Liedeke Plate to suggest that a new term or field called "amnesiology" should be established within memory studies. The discipline would be dedicated to the study of forgetting, "not as a memory impairment or margin of memory, but as something that is actively produced - as a created state that has been produced and reproduced, which must be explored separately and consequently needs its own set of tools" (2016, 144).

In the eighties, the territory of the former Yugoslavia witnessed not only a gradual decay of the common state and the rise of nationalist tendencies, but also a gradual transformation of the memorial paradigm in which attachment to Yugoslavia as a common state and as a cultural habitus for the generation born in the eighties was replaced with attachment (or limitedness) to the independent Slovenia and Western European countries. Although forgetting is a part of a natural process, its deliberate use in the creation of a new cultural environment plays an important role, as it means conscious upbringing of generations that will be bearers of new memories. Interviews on remembering an artifact such as the Yugoslav Monopoly are therefore meant as a display of the discrepancy between the memory imprinted in the game and the memories of my interlocutors. ${ }^{1}$

${ }_{1}^{1}$ Due to this conditionality, I am quoting my interlocutors' year of birth next to his/her name. 


\section{Monopoly as Metaphor}

In the Slovenian public space ${ }^{2}$, the word Monopoly holds a negative connotation. It is most often used as a metaphor for the accumulation of property or influence, as evident from, for example, the gesture of the Slovenian political youth who handed a copy of Monopoly to the mayor of Ljubljana, Zoran Janković, so he could "play this game rather than with the property of the people of Ljubljana" (delo.si). Similarly, two Slovenian researchers, Sandra Bašić-Hrvatin and Lenart J. Kučić, wanted to draw attention to negative practices using this name in their study on media ownership Monopoli: The Social Media Trading game. On the other hand, the members of the comedy group RadioGaga used the game in a more amusing context: in one of their anecdotes, a retired Slovenian politician travels to the US to consult with Donald Trump about the possibility of Slovenia becoming the 52nd State of the United States of America. In the anecdote, he explains to his interlocutor how he played Slovenian Monopoly together with Trump's son Barron:

Intelligent lad. He bought everything. He bought everything! He bought Vogel! He bought Kranjska Gora! He bought Portorož, everything, he built hotels everywhere, the only thing I was left with was the train station Zidani most and I said to myself: this is mine! Because this field is of strategic importance! (radioprvi.rtvslo.si)

In the above case, the reference to the game extends the metaphor of accumulation of wealth to the sale of Slovenian territories and real estate to wealthy foreigners. At the same time, it accuses the Slovenian politician not only of being greedy, but also of being unable or unwilling to protect the interests of his state and to recognize the strategic importance of those sites or tourist resorts that would bring the country the most profit. In this case, therefore, Monopoly serves as a metaphor for the nation-state.

An even more interesting example of the use of Monopoly as a metaphor for the nation-state is related to last year's campaign in neighboring Croatia: after announcing the news that Croatia would get its version of Monopoly and that the authors of the campaign called on citizens to vote for the cities that should be featured in the game, it turned out that the state actually already

2 At this stage, my research is limited to Slovenian interlocutors and to the Slovenian cultural space.

Board Game Studies Journal 14, pp. 109-126 DOI: $10.2478 /$ bgs-2020-0006 
had its own version of Monopoly - in the nineties, it was published by Hasbro, and its fields consisted of the streets of major Croatian cities.

Andrea, 1988. My first memory of Monopoly is the fact that I got it for St. Nicholas [...] somewhere between 1994 and 1999, I don't know what grade I was in ... Up until then, I had no idea what Monopoly was, and it was quite a hard game for me, a little child, and when we played it for the first time, we played it for a week $[\ldots]$, the family: father, mother, my sister and I were playing, of course, they were explaining everything to me, where all these streets were, this was Croatian Monopoly, therefore, these were streets of Croatian cities [...], but I know that the most expensive one was Ilica $[\ldots]$ and the first time after that when we were learning in school about Ilica, when we were learning about Zagreb, I thought: is this the expensive street from Monopoly? And so, to this day, when someone mentions the name Ilica to me, my first association is Monopoly, not Zagreb. And it was violet, I remember that too.

Given that nowadays Monopoly has not only countless national versions but also plenty of pop culture variations, such as Sponge Bob Monopoly, Queen Monopoly, Dragon Ball Z Monopoly, Game of Thrones Monopoly, Star Wars Monopoly, etc., the South Slavic integration of Monopoly with the nation-state is somewhat obsolete. The news that Croatia would get its own Monopoly was obviously misleading, intended primarily to stir up national feelings and a call to mobilize the masses.

\section{Yugoslav Monopoly and Its Playing Fields}

Yugoslav Monopoly was designed in the mid-eighties, in a period during which the country was already veering towards capitalism (Repe, Kerec 2017, 247). By then, the region was familiar with classic board games such as chess, ludo, mikado and a variety of card games. The first versions of Monopoly came to Yugoslavia from abroad, as souvenirs or gifts (Dimitrijević 2019) from Western countries where the game was already distributed. And to Slovenia especially from neighboring Italy, which issued its version of the game from the mid-thirties ${ }^{3}$ onwards.

3 The historical development of the Italian version has its own characteristics: in 1935, Arnoldo Mondadori, the owner of an important Italian publishing house, received a copy 
Kocka's Monopoly, which was designed by the company director Jože Hribar, remained in people's memories with its blue, elongated box, a yellow playing board and a color chart that divided individual places into groups of two or three (Figure 1).

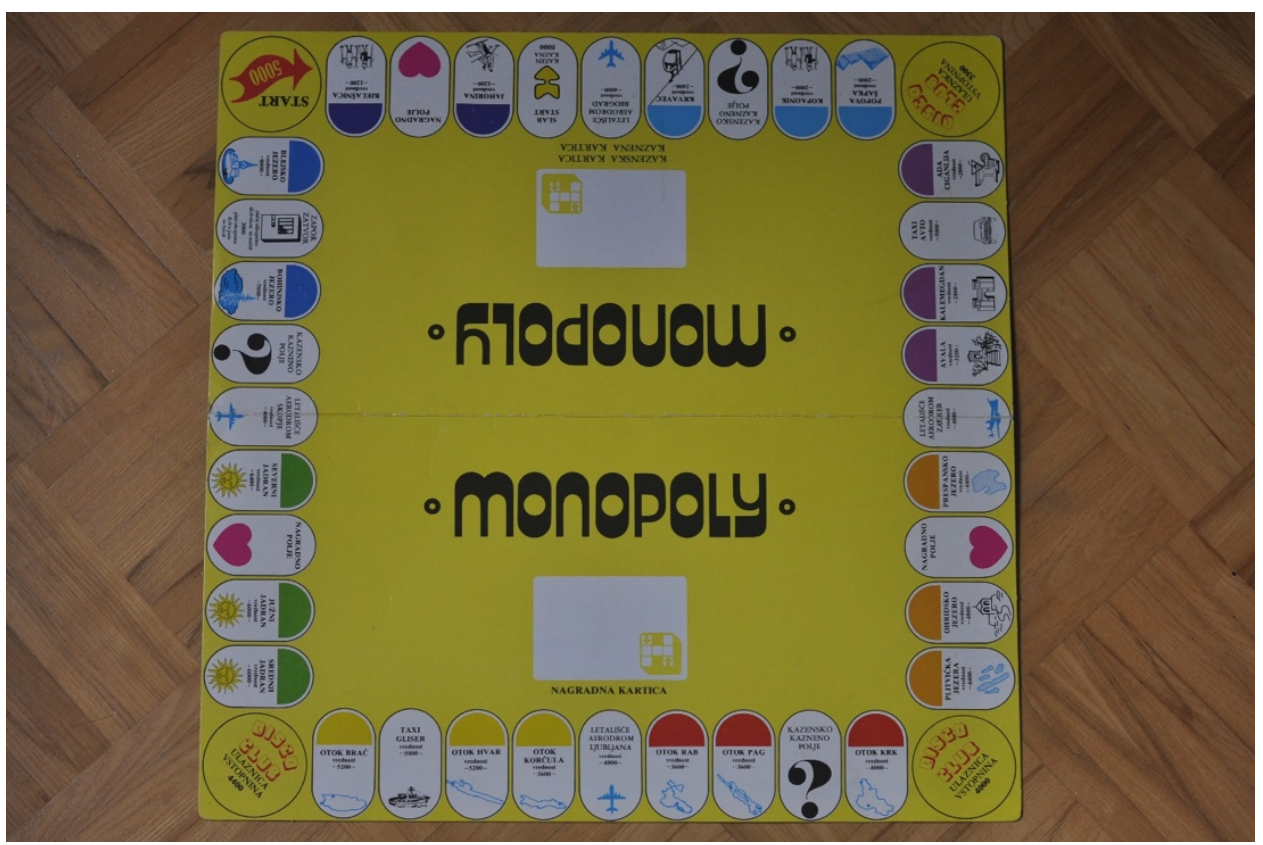

Figure 1: Monopoly Playing Board

Unlike the American version, the figurines are wooden, of the same shape and of different colors. The distinctiveness of Kocka's version is also the three corner areas represented by Disco Club. Fields associated with means of transport are marked by airports, Taxi Car and Taxi Speedboat. This version, unlike the original one, does not have a free parking space.

My interlocutors' memories of playing Monopoly were positive, as the game firstly represents to them an object of nostalgia for childhood, youth

of the board game Monopoly as a gift from America. Not interested in issuing the game, he showed it to his friend, translator Emili Cereti, who was thinking about opening his company. Italy was then a Fascist country, wary of foreign products, especially if they came from England and America, and foreign names. That is why Ceretti first changed the name of the game to Monópoli, with the final $-\mathrm{i}$ in the record. Some rules of the game were changed as well. The Italian version thus became different from the original and its rights were marketed by the Italian company Editrice Giochi (Albertarelli 2000, 120) independently of Hasbro, at least until the beginning of the twenty-first century. 
or a time spent pleasantly. I dare say that this was also one of the main reasons for many to respond to my invitation to cooperate.

Anja, 1990. I associate this [game] mainly with my family and some- now, looking back, I see - personality traits of my family members: my father never wanted to play Monopoly and we always played in the same group: my uncle, his wife and my mom and me and my sister. And it was always my uncle's initiative, him also being the most capitalistic person in the family, the most principled, but really [...] and really, he watches every penny, and he loved this [game]. Although [me and my sister] were really little at the time, we played it and he had no reservations to drive [...] a child of seven [... to bankruptcy, and then [mother] would say something like: "Come on, take it easy so that it will at least be interesting to play", but no, he was prepared to do anything, he would manipulate you into selling him everything you had, all your property, everything went to him, and he was always the bank, no one else could ever be the bank, I do not even know why we wanted to play this game, I mean, well, with him. But yes, now, seeing it in retrospect, this psychology of family members, I find it amusing.

The most important aspect in the testimonies of my interlocutors was financial. Most of them saw money as the most intriguinig feature of the game and, as children, some of the interviewees used to play with this money games that they had come up with themselves (Figure 2).

Interlocutors often emphasized the uniqueness of the Yugoslav Monopoly and the cult status it enjoyed among other games from their childhood: they all claimed to still be keeping the board game somewhere at home, be it in the attick or in their parents' house, although in a very worn-out state. The popularity of Kocka's Monopoly is also evidenced by the fact that it was included as an entry in the online project Lexicon of $Y U$ Mythology. The journalist Agata Tomažič rounded up the description of the game with the hint that the idea of Slovenian nationalism was hidden behind the distribution of playing fields and the values assigned to individual resorts, since Slovenian Bled and Bohinj (Figure 3) were the most expensive fields in the game, while the Bosnian ski resorts Jahorina and Bjelašnica were the cheapest. Moreover, according to Tomažič, with such a distribution of playing fields, Monopoly supposedly predicted the future disintegration of Yugoslavia. 


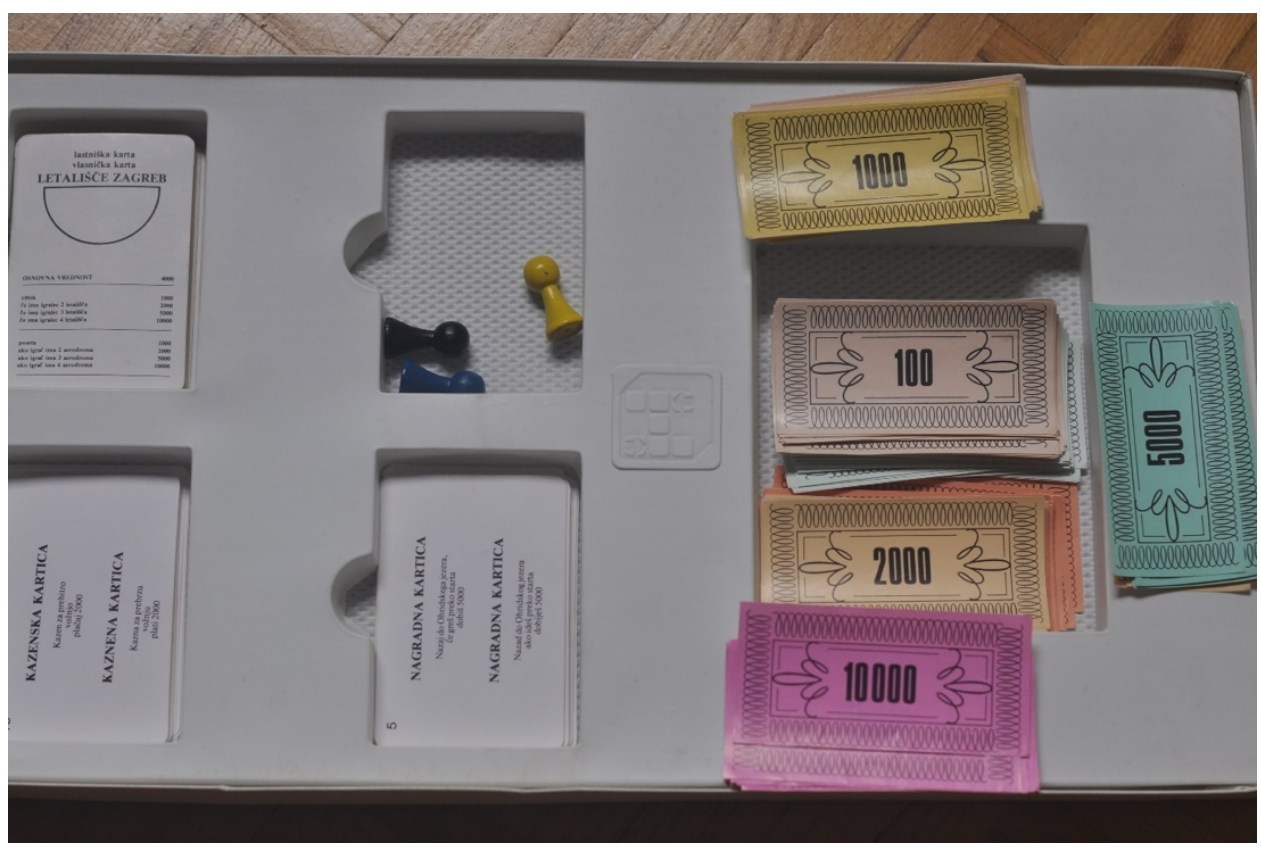

Figure 2: Monopoly playing cards and banknotes

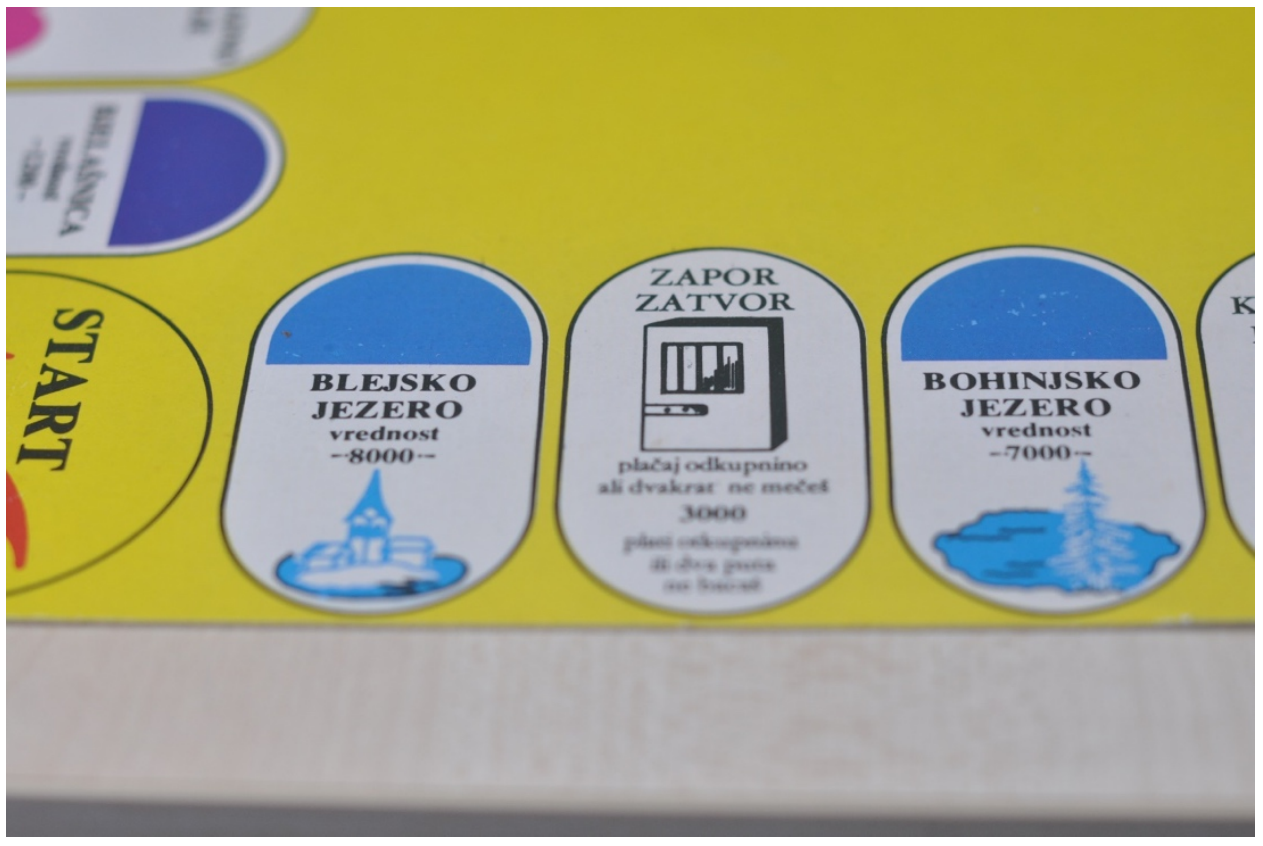

Figure 3: Slovenian resorts Lake Bled and Lake Bohinj 
The said source was one of my orientation points when I began to record interviews about the game, so I often asked my interlocutors whether they saw a message of Slovenian superiority in the field distribution chosen. The responses of the first interviewees were negative.

Špela, 1982. Do you remember that statue by Degas ... I don't know, either by him or someone else, the Frenchman, Little Dancer, right. Our high school art history teacher explained to us that this girl is standing there in half a ballet pose, with her hands behind her back and looking sideways, holding her head up slightly arrogantly. And then art historians went to investigate this; in fact, it was already scandalous at the time, because it embodied not what ballet was supposed to represent, elegance, I don't know, some ratios about the golden section, beauty, blah blah, but the dimensions of her head - a very popular theory at the time had it that the measurements of the head reveal one's character, and well, her character was one of a deviant. Seriously. That's why she was so shocking. But let's say, this was some kind of completely absurd theory, which nobody takes seriously today, just like the eugenics, right ... these things change over time ...

Although the openness of meaning, pointed out by Špela, often provokes disapproval and excessive alignment with phenomenons from our current reality, it is precisely this the condition that makes it possible for a certain work to succeed in maintaining its topicality for a longer period of time, since it enables everyone to see something they could identify with. At the same time, it should be borne in mind that our interpretation of information will consist of collective representations present in a given period on the one hand and of personal experiences of an individual influenced in particular by their memory and information acquired through education on the other.

The allocation of the playing fields in Yugoslav Monopoly could be interpreted in a variety of ways: firstly, they could be interpreted in accordance with common orientational metaphors, such as north-south and east-west (Lakoff, Johnson 1980, 25), with southern republics, as a rule, being perceived as less developed in comparison to northern ones, similarly as western ones are compared to eastern ones. Such a conception would coincide with the spirit of the eighties, when based on growing social 
differences between the republics, individual Yugoslav countries began to develop orientalist ideas of each other. Slovenia and Croatia were seen as more developed, as countries closer to European culture, while other republics belonged to the primitive, lazy and intolerant Balkans (BakićHayden 2007, 450).

At the same time, it is necessary to emphasize the solely objective circumstance that in Monopoly, the most expensive field is always the last. On the one hand, the fields in the game are allocated thematically (ski resorts, lakes, islands, etc.) and with ascending value, while on the other hand roughly speaking - they follow each other from south to north. With such an arrangement, the game may have provided a clearer picture of individual republics and, finally, of the common state. That is probably why interlocutors who still shared the collective memory of Yugoslavia were not surprised by the distribution of the fields, and they estimated that the thesis on nationalism was imposed on the game at a later stage.

XX, 1989. Have you ever linked the resorts [in the game] to
values or have they affected your perception of these
resorts?
Peter, 1974. Yes, you know what ... this is a very complex
question. I basically knew that Yugoslavia was divided. That the
Slovenian standard was higher than that at Ada Ciganlija. I think
that Ada Ciganlija was the first or the second, when you start,
followed by Avala, Kalemegdan, Lake Ohrid [...] To me, it was
self-evident how they distributed the fields. The standard in
Slovenia was simply higher and so, Bled and Bohinj were at the
end of the game, as the Postojna Cave was not as developed as it
is today.

When I almost gave up on the interpretation discussed above, I managed to record some testimonies in which the interlocutors claimed that Monopoly gave them a sense of Slovenian superiority.

Špela, 1985. When I was a little girl and we used to play this, I used to ask myself: what's with the Serbs that we gave them such low prices? Damn! Bled is nothing special, we go there every holiday. I used to ask myself this question a lot, maybe, if the Bosnians had their own version, maybe some of their [fields], I don't know, Jajce, were that big...

Board Game Studies Journal 14, pp. 109-126 DOI: $10.2478 /$ bgs-2020-0006 
Although Špela talks about the sense of Slovenia's superiority, supposedly deriving from the game, her thoughts offer two arguments against the above-mentioned thesis: questioning why a particular field is more valuable than the other is common and can also be found in testimonies of interlocutors who played other versions of Monopoly ${ }^{4}$. It is also very likely that if the game had been designed in any other republic, the fields would have been arranged in such a way that one of their tourist resorts would be rated the highest, again finding arguments for the justification of such distribution as against it.

In my opinion, the game was not designed with regard to some kind of theory of superiority or nationalism. In a more detailed analysis of what the testimonies in discussion have in common, I found that the interviewees were all born in the second half of the eighties or early nineties. Hence, if we are talking about the origins of Slovenian nationalism, these did not emerge from the game, but rather from the environment or the reality as experienced by the interlocutors born in the second half of the eighties: the cultural space that Slovenians of this generation recognized as their own was mostly limited to Slovenia as an independent state, and the said period was also a time when nationally colored stereotypes reached their peak. Feelings of superiority are thus rather projections of my interlocutors' perceptions onto the game and not the other way around.

Nina, 1986. ... and I remember asking daddy and Tomaž, where is that, what is that and how it stayed with me that Ohrid and all those fields at the beginning, Bjelašnica or whatever it was, are inferior, and Slovenian fields, Bled and Bohinj, were far more expensive, and so I remember how long this impression stayed with me: well there's just rubbish there.

\section{Gultural Habitus}

${ }^{4}$ In addition to the Yugoslav Monopoly and the Hasbro Monopoly (where Portorož is the most expensive field), the game of the unknown manufacturer Monopol! was also in circulation in the 1990s, where the Austrotel Hotel in Ljubljana was the most expensive field. One of the interviewees, who played the game at a young age, recalls that she often wondered why the field was more expensive than, for example, the Dobrna spa. She thought the thermal complex was more prestigious than a hotel, even though it was a facility in the Slovenian capital.

Board Game Studies Journal 14, pp. 109-126 DOI: $10.2478 /$ bgs-2020-0006 
The geographical aspect, which in the memory of my interlocutors did not play as significant a role as money or memories of their teammates, played a more important part in testimonies of those interviewees who got acquainted with the game as children. The association of Monopoly's playing fields with realities from their own environment is a constant in the answers, the more so if they first learned about a certain resort or street in the game - regardless of which version they played.

An additional constant in my interviewees' answers is their awe of places or fields of which they had never heard before. At this point, the narrative of the testimonies goes on to describe interactions with other players, in particular witholder ones (mostly parents or older siblings), explaining to my interlocutors what a certain geographical concept was supposed to represent. This was not so much a systematic lesson as a quenching of momentary curiosity.

\section{$X X$. Those places you were not familiar with. Did you ever wonder where they were?}

Nina, 1982. We always asked those older [than us], as I said, I used to play this with my uncle a lot, he was a bit older, and he presented me with the map of Yugoslavia and so on. We also played [Monopoly] with our parents and they always said a few words, because they had this knowledge and so on. Since we did not receive it, at least not in kindergarten, and then later on, there was no such education.

It should be emphasized that Nina was the only interlocutor who pointed out that her relatives had presented her with the map of Yugoslavia. To the rest of my interviewees, the location of a certain resort was explained with its position in a particular republic. Therefore, they could accept and interpret the game, again, in accordance with their own reality and without reference to Yugoslavia.

Anja, 1990. Well, but I actually didn't, I didn't connect this with Yugoslavia. I really had this feeling: aha, this is in Croatia, I was thinking this way: aha, this is in Bosnia. Always when we discussed this, I think, [my parents] always spoke this way. I mean, they were not some Yugonostalgic people, after all. [...] And they always spoke in these terms, and there was no such feeling, well.

Board Game Studies Journal 14, pp. 109-126 DOI: $10.2478 /$ bgs-2020-0006 
Tina, 1981. For example, I never went to look on the map, because at the time, the map was a foreign concept to me, I think geography was, too... I knew Slovenia, I mean [I think I knew how] Yugoslavia looked like and that was it. Usually, father was watching TV, and it was usually like this: daddy, where is that? We came all the way there and he then told us where this is or where that is. It stopped there. If daddy didn't know, it was not important (laughter) because he knew everything, right. Of course, right.

Rather than parents and relatives, the more important role in the reproduction of cultural memory is played by intellectuals, politicians, schools and the media (Portelli 2007, 272). For my interviewees, awareness that the game actually represented fields from the former Yugoslavia came years later - or not at all - while the resorts which for the previous generations represented a part of a common cultural habitus remained somewhere there or far away. Or, in most cases, in the game Monopoly, which has often remained the only tangible association for the geographical terms mentioned in it.

Nina, 1986. They explained to me [where these places are] ... but it was so [abstract]. At that time, I did not understand this geographically. Even what Macedonia was, or I don't know /.../ I know that it was later, later in elementary school, when we had maps: aha, that's what I saw in Monopoly.

\section{Do you have any concrete examples?}

Nina, 1986. Not really [...] it's very funny, actually, just a couple of years ago, when I was in Ohrid, [and the first association that I had was] with Monopoly. And that's how it was: I'm going to Ohrid, that was in Monopoly (laughter).

$X X$. And then, when you got there, you said: yes, I'm here! Nina, 1986. Really, so interesting. [...] I cannot remember anybody explaining these things to me, but I do remember being aware that this was very far away. Again: I asked [where] this is very far. We can't go there by car.

"What is not remembered, is not only unavailable or inaccessive psychocognitively, it is also unavailable in language" (Plate 2016, 145). Interlocutors 
who did not associate sympathies for a particular field with their personal experiences of spending holidays there were picking their favorite fields according to a certain color they liked or the sound of a particular word. On the other hand, solely thinking about the sound of a certain geographical name suggests that someone first heard it playing Monopoly. In this respect, Ada Ciganlija (Figure 4), a bar district in Belgrade, had a special place in the testimonies of my interviewees: given that the word "cigan" means "gipsy" in Slovenian, it was often associated with gypsies or circus tents in the childhood imagination of my interlocutors.

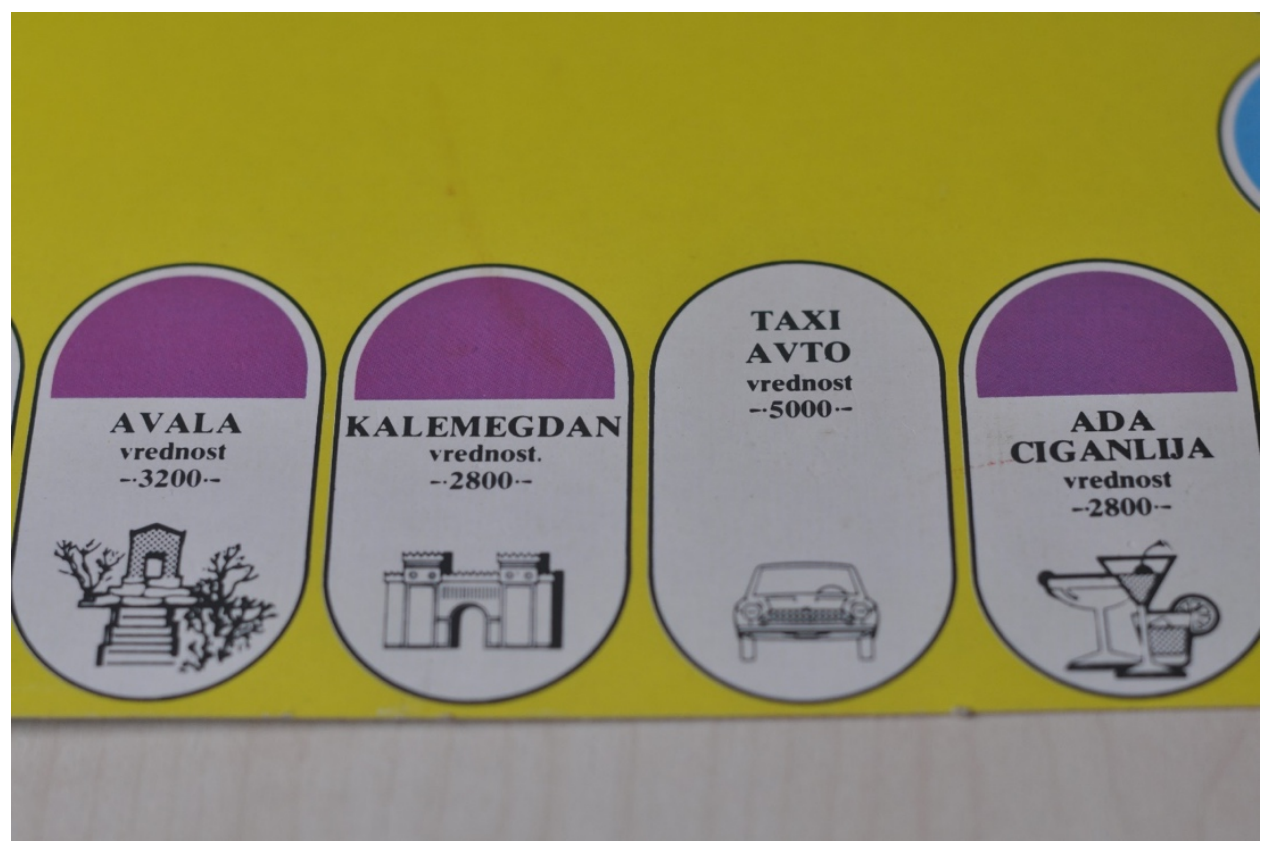

Figure 4: Belgrade districts Avala, Kalemegdan, Ada Ciganlija and Taxi car between them

$X X$. Did you ever ask yourself where all these places were? Tanja, 1985. I didn't know until we went to the seaside in Dalmatia.

$X X$. Ok, so you didn' know but-did you think that these places were real or fictional...

T. I don't know. I guess I knew they were real since Bled and Bohinj were included, only I think I never asked myself this 
question [...] I didn't know whether this is Croatia or Bosnia or is this ... Jahorina, Bjelašnica, these two to me were: Say what? Ha? These names really sounded like fiction to me, that they did not really exist. Afterwards, when I heard that there even was a ski resort there, I was completely shocked. I learned that a few years ago ... No, really, I learned it probably two years ago when one of my pupils said they were going skiing there, to Jahorina...

\section{$X X$. And what did you make of it?}

Nothing, I was shocked. I remembered Monopoly and the fact that I had kept on thinking that this place did not exist.

Games are a place of fiction (Huizinga 2003): a space that is separate from reality and in which specific rules apply, geographic fields being only a minor part of this game that may or may not originate from reality. In the answers of interlocutors who considered the resorts from Monopoly as imaginary or fictitious or as "whatever" - I must stress that they did not constitute the majority of my respondents - their answers, in my opinion, should not be interpreted as referring to fiction in the true sense of the word. The age of my interlocutors plays an important role: as children, they either did not know how to imagine these places geographically or their names represented something sounding so strange, so foreign, so remote and exotic that they seemed to them as if they were fictitious, the more so if they had never heard of these places outside the space of the game. In such cases, the re-confrontation with a certain geographical concept was all the more surprising. Again - years later.

$X X$. Have you ever had this moment of surprise, that you went somezhere, and you said to yourself ...

Katja, 1989. Yes, those were, how do you call them, Plitvice Lakes (Figure 5), when we went to the Croatian seaside. Like: you see the board - is it "National Park" written next to "Plitvice Lakes"? Something like that. Oh! So, this is actually here? OK, OK (laughs). But it was only in high school that I realized it. Or when we started to travel a little further south to the Dalmatian coast. But earlier, well I guess I might have heard about them and I already knew that they existed somewhere, but I always thought that they were somewhere very, very far away. Then, when we 
drove a little further south, and I saw that board, I said to myself: wow, this is so close...

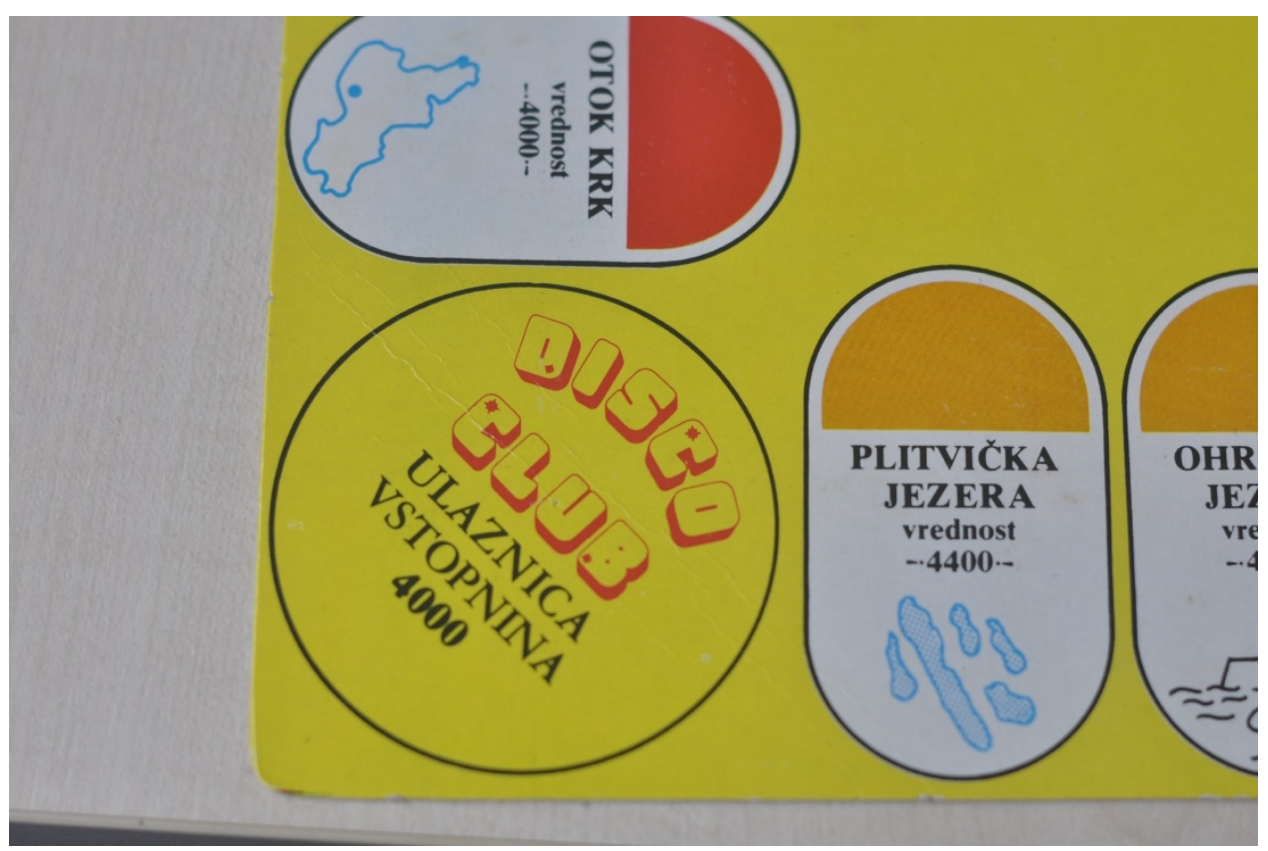

Figure 5: Plitvice Lakes and the Disco Club field

\section{Conclusion}

In the article at hand, I have tried to show how quickly a certain cultural habitus may disappear or how quick the occurrence of oblivion is: the generations born in the eighties and growing up in the nineties were spatially-mnemonically attached to Slovenia as an independent country, and were left to their family connections or research on their own initiative when it came to exploring Yugoslavia as a former common cultural habitus.

Tina, 1981. I am lazy by nature. [...] I think that's why I never went to look these things up on the map. I just didn't feel any need to do so: daddy, tell me if you know where this is, if not, I don't need to know either. 
$X X$. Actually, no one said that they went to check these things. The parental motive was really key: this is in Serbia, this is here, this is there.

Tina, 1981. See, I didn't even know where Serbia was. OK, a part of Yugoslavia, because I didn't know exactly where it was, a part of [the country]. I don't know if I ever had the need to place a certain resort somewhere on the map, because I was not even, I knew how Yugoslavia looked like, but I did not know, I mean, why do I need to know where Dubrovnik is [...] well, what use do I have if I place Belgrade somewhere on the map, if I do not even know, I cannot imagine the size of a country, and I cannot imagine where we are, if my view reached towards Murska Sobota, where I had relatives, up to Carinthia, half to there, Istria where we went to the seaside, Novigrad, Crikvenica, no further, right. That's it. I do not need to know anything else.

For many, Yugoslavia remained somewhere there or far away. On the other hand, it is a matter of oblivion - induced or not - that gives each generation the opportunity to create their own memory or to construct their own narrative, which makes it different from the previous generations as well as from those that are yet to come.

People create objects which represent their social reality, and at the same time, these objects affect them as well. However, when it comes to board games, it is important to study not only their material side and the distribution of certain playing fields, but also their reception: what precisely is communicated through a game does not depend solely on the game itself, but also on our interpretation, which also depends on our current historical and social reality. In the theory of material culture, it is often said that objects talk (Mlekuž 2011), but, at the same time, what they tell us is often the projection of our own ideas; sometimes, we put the words in their mouth ourselves.

Translation: Manca Gašperšič

Declaration of Conflicting Interests: The author(s) declared no potential conflicts of interest with respect to the research, authorship, and/or publication of this article.

Funding: The author(s) received no financial support for the research, authorship, and/or publication of this article. 


\section{References}

[Albertarelli, 2000] Albertarelli, S. (2000). "1000 Ways to play Monopoly." In: Board Games Studies fournal, Vol.3, 117-123.

[Auge, 2004] Auge, M. (2004). Oblivion, Minneapolis: University of Minesota Press.

[Bakić-Hayden and Hayden, 2007] Bakić-Hayden, M. \& Hayden, R. M. (2007). "Orientalistične različice na temo 'Balkana': simbolna geografija v nedavni jugoslovanski politiki kulture. In: Jeffs, N. (ed.), Zbornik postkolonialnih študij. Ljubljana: Krtina, 441-459.

[Huizinga, 2003] Huizinga, J. (2003). "O izvoru kulture v igri." In: Strehovec, J. (ed.), Teorije igre, 7-137. Transl. by S. Knop. Ljubljana: Študentska založba.

Delo.si (2013), Zupan Fanković pravi, da ga je zabolelo, http://www.delo.si/novice/kronika/zupan-jankovic-pravi-da-ga-jezabolelo.html [Accessed July 12, 2018].

[Dimitrijević, 2019] Dimitrijević, U. (2019) Da li je ova društvena igra bila zabranjena u Jugoslaviji, https://www.bbc.com/serbian/lat/balkan46459474 [Accessed 29.07.2019].

[Lakoff and Johnson, 1980] Lakoff. G. and Johnson, M. (1980). Metaphors We Live By. Chicago and London: University of Chicago Press.

[Miller, 2016] Miller, D. (2016). Materialna kultura. Transl. by P. Petek. Ljubljana: Studia Humanitatis.

[Mlekuž, 2011] Mlekuž, J. (ed.), Klepetavi predmeti: ko predmeti spregovorïo o nas in o drugih. Ljubljana: ZRC SAZU, 2011.

[Peterson, 2012] Peterson, J. (2012). Playing at the World. San Diego: Unreason Press. 
[Plate, 2016] Plate, L. (2016). "Amnesiology: Towards the Story of Cultural Oblivion.” In: Memory Studies Fournal, 9(2), 143-155.

[Portelli, 2007] Portelli, A. (2007). The Order Has Been Carried Out: History, Memory and Meaning of a Nazi Massacre in Rome. Basingstoke: Palgrave Macmillan.

radioprvi.rtvslo.si, Radio Ga Ga (video prenos). Accessed May 5, 2017. https://radioprvi.rtvslo.si/2017/05/radio-ga-ga-110/ [Accessed July 9, 2018].

[Repe and Kerec, 2017] Repe, B. \& Kerec, D. (2017). Slovenïa, moja dežela: družbena revolucïa v osemdesetih letih. Ljubljana: Cankarjeva založba.

[Tomažič] Tomažič, A. "Monopoly." Leksikon $Y U$ mitologïje. http://www.leksikon-yu-mitologije.net/monopoly/ [Accessed July 12, 2018].

[Whitehill, 1999] Whitehill, B. (1999). "American Games: A Historical Perspective.” In: Board Games Studies Fournal, Vol. 2, 116-143.

[Whitehill, 2015] Whitehill, B. (2015). "Games of America in the Nineteenth Century." In: Board Games Studies fournal, Vol. 9, 65-87.

Zala Pavsičc,

Faculty of Media,

Ljubljana, Slovenia

zala.pavsic@fame.si 